\title{
The Effectiveness of Using Collaborative Strategic Reading (CSR) on Students' Reading Comprehension of Narrative Text
}

\author{
Narindia Lisandy 1), Nuryansyah Adijaya ${ }^{2)}$ \\ 1) SDS Jakarta Emerald School, Kebayoran Lama, Jakarta, Indonesia \\ 2) Universitas Esa Unggul, Kebon Jeruk, Jakarta, Indonesia \\ 1) narindia241@gmail.com, ${ }^{2)}$ nuryansyah@esaunggul.ac.id
}

\begin{abstract}
This study aimed to find out whether or not the use of collaborative strategic reading (CSR) will be effective on students' reading comprehension of narrative text. The study used a quantitative method with pre-experimental design. The instruments used in this study were pre-test and post-test and the subjects of this study were the tenth-grade students of MA Annida Al-Islamy. The data were analyzed by using the t-test. The results showed that the students mean score in pre-test was 64 while in post-test mean score was 78. The result of this study analysis obtained $8.439 t_{0}$ and $2.045 t_{t}$ with significant of $5 \%$. Thus, it can be said that the use of collaborative strategic reading (CSR) on students' reading comprehension of narrative text was effective.
\end{abstract}

Keywords: collaborative strategic reading (CSR), narrative text, reading comprehension Citation APA Style: Lisandy, N., \& Adijaya, N. (2019). The Effectiveness of Using Collaborative Strategic Reading (CSR) on Students' Reading Comprehension of Narrative Text. English Language in Focus (ELIF), 2(1), 53-58.

\section{INTRODUCTION}

$\mathrm{N}$ owadays, English has a wide influence in the world because most of the world information and knowledge are written in English. English also has a significant role in many various fields such as business, travel, technology, education, economy, politics, entertainments, etc. In Indonesia, English has been taught in every level of the school, starting from primary school until senior high school. Moreover, English also used as the major subject at university and English become one of the requirements to graduate in middle school. In short, students are expected to be mastered the English language both in oral and written.

In learning English four skills should be mastered by every student that are listening, speaking, reading and writing. Reading became one of the skills that are not easy to learn, because in learning reading the students are not only required to understand the meaning of each word and have to comprehend the entire of reading the text but also expected to read the text in good pronunciation. It is supported by Grabe \& Stoller (2011, p. 24) which state that 
reading is the ability in interpreting the meaning and the information from written text appropriately. Thus, reading becomes essential because the students can get current information and can enhance their knowledge by reading activity.

According to Snow (2012, p. 1), reading comprehension is a process to get a precise understanding of the author's message. In which to comprehend the text, the readers have to construct and collaborates their prior or background knowledge with the information in written text simultaneously. When the students want to learn reading comprehension, of course, they need a type of reading text that they will read. Besides, in reading there are several types of reading text such as narrative text, report text, recount text, procedure text, etc. In this study, the writer will choose one of the various types of reading text that to be used as a discussion, namely narrative text.

Anderson \& Anderson (2010, p. 8) defined narrative text as a piece of text that tells a story and narrative text there is orientation, complication or problem, the sequence of events, resolution, and coda and it has the purpose to amuse and entertain the reader. In Indonesia, narrative text is a type of text that should be taught by the teacher and learned by the students at the first grade of Senior High School, because it was established in Curriculum of Senior High School and was recommended by the Government. Based on Standard of Competency and Basic Competence (SKKD), in the aspect of reading the first-year students of senior high school have to be able to comprehend a narrative text both in oral or written simple short story.

Narrative can be a factual or imaginary story to entertain the reader. It is called imaginary because the story is not necessary tells the truth but it could be just imagination or fictional story that made by someone or a group of people who have not proven the truth. The example of an imaginary story is like fairy tales, legends, romances, mysteries, fables, myths and adventure stories. As Anderson \& Anderson (2010, p. 18) described many different types of narrative; namely humor, fantasy, romance, historical fiction, crime, reallife fiction, mystery, science fiction, diary novel, and adventure.

Based on the writer's experience while doing PPL and observing the tenth grade of Senior High School, the writer found that while learning reading comprehension especially in the narrative text many students are faced some difficulties, one of the problems is they found a lot of unfamiliar word in the text. So for the students, reading narrative text is considered as a boring activity for them because while in reading the student found many problems such as they are required to comprehend a whole reading text, find the main idea, conclude the content of the text and at the end they have to answer the question related to the story correctly. In reality, the teachers' role in the teaching process is important to help the students develop their reading comprehension. Because the role of the teacher is as facilitator and motivator for students in which the teachers have to be responsible to the students' achievement in the class and need to prepare and 
select a good teaching material appropriately, to help the students gained the maximum result of their reading test. It is in line with McDonough \& Shaw (2012, p. 90) state that teachers should provide materials that stimulate interest for their students.

Based on the problem above, the writer considers the teacher is necessary to use the appropriate strategies in teaching that can help the students to build their pleasure and interest in reading and can help them to comprehend reading text easily, especially in comprehending narrative text. One of the strategies that can help the students to develop their reading comprehension is by using Collaborative Strategic Reading (CSR). According to Klingner, Vaughn, \& Boardman (2015), CSR is a collaborative technique that teaches students to use comprehension strategy while working cooperatively. Students strategies include previewing the text; giving ongoing feedback by deciding "click" (I get it) or "clunk" (I do not get it) at the end of each paragraph; "getting the gist" of the most important parts of the text; and "wrapping up" key ideas. The objective of Collaborative Strategic Reading (CSR) is to improve the students' reading comprehension by working together in a group and by this strategy the students are expected to understand the reading material better. As the result, the students are not only able to have better comprehension in reading but they also have a good communication skill with other students in the group and the students can resolve the problem in reading comprehension.

Collaborative Strategic Reading (CSR) has its purpose. According to
Andanawati (2013), the purpose of CSR is to increase the students' reading comprehension and the students' conceptual learning in which to maximize it students have to participate in a group. Another purpose of CSR is to improve the students reading comprehension skill in learning disabilities or at risk for reading difficulties. In sum up, the objective of Collaborative Strategic Reading (CSR) is to facilitate the students in improving their reading comprehension by working together in groups and to better understand the material in their reading tasks.

Klingner, Vaughn, \& Boardman (2015) state two phases can be implemented in Collaborative Strategic Reading (CSR) there are: (1) teaching the strategies, and (2) cooperative learning group activity. Teaching the Strategies. In this phase, the teacher explains the four steps and strategies that should the student do while using Collaborative Strategic Reading (CSR). The four strategies are preview, click and clunk, get the gist and wrap up. Preview is done before the students read the entire text of the story, click and clunk and get the gist are done when the students are reading the text. Meanwhile, the wrap-up is done after the students read the entire text of the story. Cooperative Learning Group Roles. In cooperative learning group, each student must have their respective roles which aim the students can be responsible and be active during the learning process and in the cooperative group the students are required to have good communication and intellectual abilities to work effectively and productively. 


\section{RESEARCH METHODOLOGY}

I $\mathrm{n}$ this study, the writer used a quantitative method by using preexperimental design. Quantitative research designs were done either in descriptive (the subject usually measured at once) or experimental (the subject measured before and after treatment).

A descriptive study established only associations between variables and experimental study established causality. Quantitative research focused on numeric, detailed, unchanging data and used convergent reasoning rather than divergent reasoning. The writer will measure out experimental class by using one group pre-test and post-test. According to Fraenkel \& Wallen (2011, p. 265), in the one-group pretest-posttest design, a single group is measured or observed before and after being exposed to a treatment of some sort.

In collecting the data, both pre-test and post-test were used as the instrument. Some steps used by the writer as follows:

1. Pre-test. The pre-test was carried out before the writer applied the treatment at the first time. This test aimed to find out the students' ability to reading comprehension of narrative text before the treatment.

2. Treatment. The treatment was conducted after the pre-test was administered. It was given during eight meetings excluding pre-test and post-test and using Collaborative Strategic Reading (CSR).
3. Post-test. Post-test was carried out after the writer applied the treatment and it was the final test. It was conducted to measure how effective using Collaborative Strategic Reading (CSR) on students' reading comprehension of narrative text.

The pre-test and post-test were in the form of multiple choice. The pre-test and post-test consisted of twenty questions. The materials were adapted from the English for Senior High School Grade X published by Erlangga and from the web. Then, The analysis of data was done after the writer get the students' reading comprehension in both tests: pre-test and post-test. To analyze the effectiveness of using collaborative strategic reading (CSR) on students' reading comprehension of narrative text is using t-test statistical analysis.

\section{FINDING AND DISCUSSION

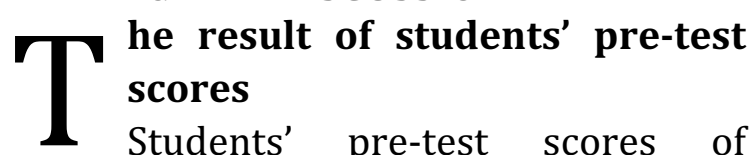
reading narrative text were presented in the following Diagram.

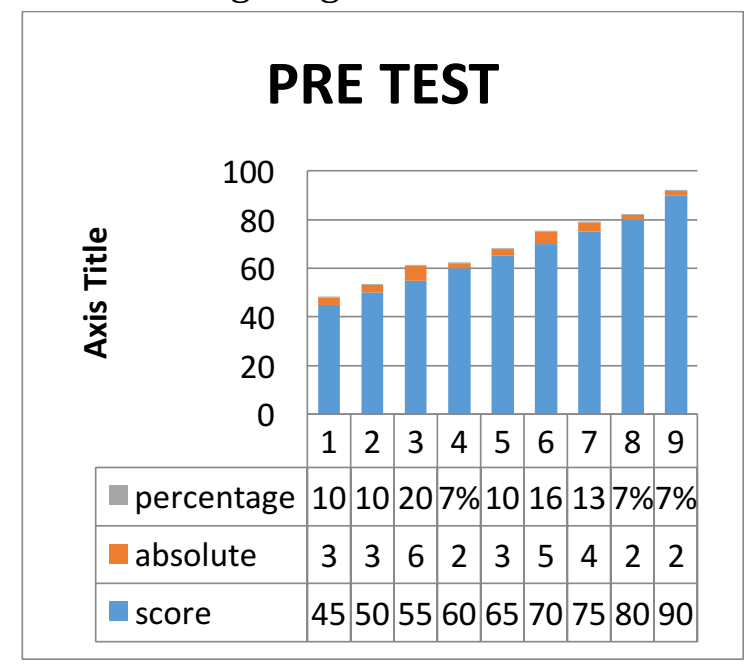

Figure 1. Diagram of Frequency Distribution of Pre-Test 
It can be seen the diagram above 3 students got lower score 45 (10\%), 3 students got middle score $65(10 \%)$ and 2 students got upper score 90 (7\%).

\section{The Result of Students' Post-Test Scores}

Students' post-test scores of the simple past tense were presented in the following Diagram.

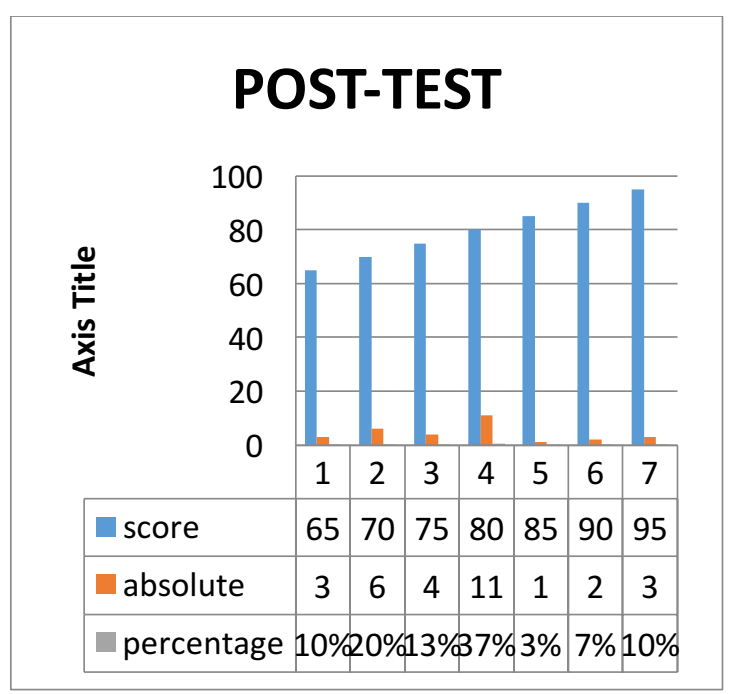

Figure 2. Diagram of Frequency Distribution of Post-Test.

Based on the result analysis of the data above it is explained that before giving the treatment the total of students' pre-test score was 1.920 and after giving the treatment the total of students' posttest score increased to 2.345 and the comparison score between pre-test and post-test was 425 . So, the determine to mean of difference score of pre-test and post-test was 14.17 and the result of (post-test - pre-test) - determine) or ( $\left(x_{j}\right.$ $\left.\left.-x_{i}\right)-\bar{D}\right)$ was -0.1 and (posttest - pretest) - determine $)^{2}\left(\left(x_{j}-x_{i}\right)-\bar{D}\right)^{2}$ was 2454.167. The result of T-test calculation before 8.439 was obtained in the degree of freedom (df) of 30 (30-1=29). With the degree significant $5 \%$, it gained score of 2.045. The result of the calculation above showed that $\mathrm{t}_{\mathrm{o}}$ (t-observation) 8.439> $\mathrm{t}_{\mathrm{t}}(\mathrm{t}-$ table) 2.045. Since the result of $t_{0}$ was higher than $t_{t}$ the alternative hypothesis $\left(\mathrm{H}_{\mathrm{a}}\right)$ was accepted and the null hypothesis $\left(\mathrm{H}_{\mathrm{o}}\right)$ was rejected.

From the explanation above, it can be concluded that there was a significant difference between the students' result of the experimental class before and after this strategy was applied. The mean result of the pre-test was 64 . Meanwhile, the mean result of the students' post-test was 78. Finally, from the interpretation above, the writer could summarize that the students' post-test result higher than the students' pre-test result. In other words that using Collaborative Strategic Reading (CSR) was effective on students' reading comprehension of narrative text at the tenth-grade students of senior high school..

\section{CONCLUSION}

his study was conducted by using
pre-experimental design which
was intended to get the effectiveness of using Collaborative Strategic Reading (CSR) on students' reading comprehension of narrative text. Based on the statistical calculation at the previous chapter in the explanation above, it can be concluded that the experimental class result had different significance between before and after the writer applied the strategy. Then, after eight meetings of the treatments, the students got the higher score on the posttest result than the pre-test result. The result of the pre-test was 64. Meanwhile, the result of students' post-test was 78 . The result showed that the score of t-test 8.439. Comparing each score in the degree of significance $5 \%$, the calculation 
showed $8.439>2.045$. It means that the Null-hypothesis $\left(\mathrm{H}_{0}\right)$ is rejected and the alternative hypothesis $\left(\mathrm{H}_{\mathrm{a}}\right)$ is accepted. It can be concluded that by using Collaborative Strategic Reading (CSR) is effective on students' reading comprehension of narrative text at the tenth grade of MA Annida Al-Islamy.

\section{REFERENCES}

Andanawati, D. (2013). The Use of Collaborative Strategic Reading (CSR) in Reading Comprehension. Bandung: Universitas Pendidikan Indonesia. Unpublished Thesis.

Anderson, M., \& Anderson, K. (2010). Text Types in English 3. Australia: Macmillan Education Australia.

Fraenkel, J. R., \& Wallen, N. E. (2011).
How to Design and Evaluate Research in Education. New York: McGrawHill.

Grabe, W., \& Stoller, F. L. (2011). Teaching and Researching Reading. New York : Routledge.

Klingner, J. K., Vaughn, S., \& Boardman, A. (2015). Teaching Reading Comprehension to Students with Learning Difficulties. New York: Guilford Publications.

McDonough, J., \& Shaw, C. (2012). Materials and Methods in ELT: A Teacher's Guide. Wiley: Blackwell Pub.

Snow, C. E. (2012). Reading for Understanding: Toward an R\&amp;D Program in Reading Comprehension. United States: RAND Corporation. 